\title{
Difficulties in Teaching English Language to Grade Nine at the Fundamental Stage in Misurata City
}

\author{
Omar A. Albukbak ${ }^{1}$ \\ Faculty of Arts - Misurata University
}

Received: 05-5-2019 Accepted: 12-6- 2019 Available Online: 24-6- 2019

\begin{abstract}
This research paper attempts to identify some problems and difficulties that impact the teaching of English language in grade nine in four fundamental stage schools in Misurata city. The study tries to explore what barriers and obstacles learners and teachers might face in the learning-teaching process. The research methodology underlying this research paper is a questionnaire. The questionnaire is administered to three sample groups: teachers, students, and inspectors of English. The presentation of the results of the questionnaire showed an illustration of several difficulties and problems that are encountered in the process of teaching English as a foreign language in the fundamental stage. These problems in brief are: the high number of students in class, the lack of qualified English teachers who could teach the syllabus appropriately, some teachers do not follow the instructions available in the teacher's book, the interference of the Arabic language on the English language, the students' feeling when asked to speak in English, pronouncing some English sounds, and learning the English writing system. The results and discussion of the study suggest how to overcome these difficulties and problems by following the modern teaching strategies and approaches and their implications in classrooms.
\end{abstract}

Keywords: Teaching English, teacher training, communicative language teaching.

1o.albukbak@art.misuratau.edu.ly

https://misuratau.edu.ly/journal/arts 
صعوبات في تدريس اللغة الإنجليزية في الصف التاسع من مرحلة التعليم الأساسي في مدينة مصراتة

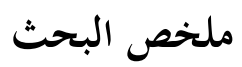

يهدف هذا البحث إلى دراسة بعض المشاكل و الصعوبات التي يمكن أن تؤثر في تدريس اللغة الانجليزية في الصف التاسع من مرحلة التعليم الأساسي بمدينة مصراتة. وتحاول الدراسة

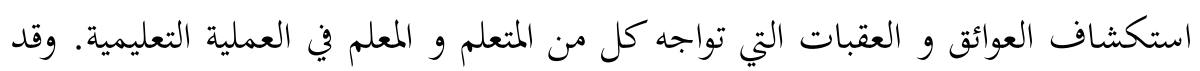

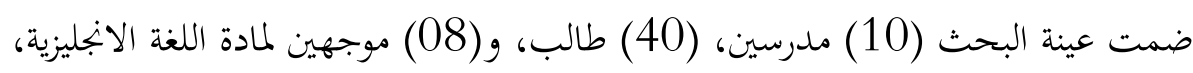

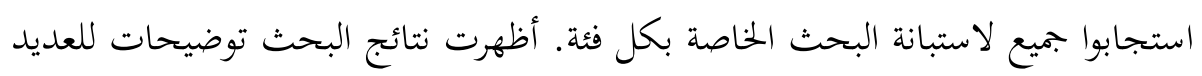

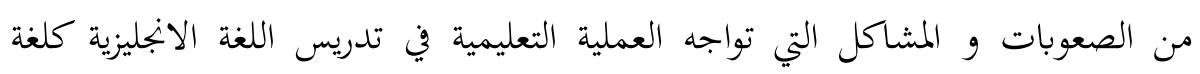
أجنبية في مدارس مرحلة التعليم الاساسي منها العدد المرتفع للطلبة داخل الفصل الدراسي، ونقص المعلمين الأكفاء القادرين على تدريس المنهج بالطريقة الملائمة، بعض المعلمين لا لا

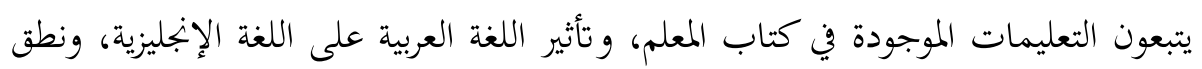
بعض الأصوات في اللغة الإنجليزية، وقدمت هذه الدراسة من خلال النتائج و المناقشة

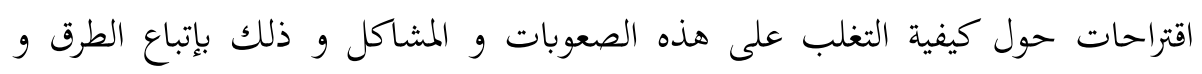
الاستراتيجيات الحديثة في التدريس و تطبيقها في داخل الفصل الدراسي. الكلمات الدالة: تدريس اللغة الانجليزية - تدريب الملدرسين - التعليم التواصلي للغة.

\section{Introduction}

\subsection{Goals of teaching English}

The educational policy in any language teaching context aims at achieving specific objectives. For instance, enabling students to comprehend English in its all manifestations and training them to develop their skills. Furthermore, increasing student's vocabulary and developing their desire to study the language to pursue higher studies, and to improve students' fluency and accuracy. Macfarlane and Farrell 
(2004) mention that the English language course in Libya is designed to further develop understanding of the grammatical system, to increase the students' range of active vocabulary and to extend their ability in the four language skills of reading, listening, speaking and writing. Phillips et al. (2000) add that the purpose of the reading and listening texts is not to teach or practise reading or listening, but rather to impart knowledge about the subject concerned and present associated vocabulary. However, the method used throughout the course ensures that whilst students are learning the new subskills of reading and listening, they will get constant practice of these subskills. In addition, the pieces of writing present the information they contain and also highlight different writing genres and give students practice in identifying the type of writer, the intended audience and the intended purpose of a piece of writing.

\subsection{Significance of the study}

While there have been several studies examining the different aspects of English language teaching in the Libyan context, this study focuses on the practical difficulties and obstacles that may face the learning-teaching process of English language at the fundamental stage at schools in the city of Misurata. Understanding the situation could provide essential information to the language teachers on how to teach the language appropriately and effectively. The present study aims to fill the gap in this research literature. The results of the study may have important implications for language learning and teaching.

\subsection{Research questions}

The study sets out an answer the following research questions:

a) What are the problems and difficulties that face students and teachers at nine grade in the fundamental stage in learning and teaching English language?

b) How to overcome these problems and difficulties, if there is any, and what are the steps to be followed in order to develop English language teaching in schools?

https://misuratau.edu.ly/journal/arts 


\section{Literature Review}

\subsection{Using first or target language in classroom}

There are various ways in which the first language (L1) can be used in teaching the second language (L2). Some methods have confirmed that the L1 use is a supporting feature to both the teacher and the student such as the Grammar Translation Method (GMT) and the humanistic approaches. In GTM, it is thought that L1 is the vehicle the students rely on to learn about the grammar and vocabulary of the foreign language (FL). According to Rivers (2015), in order to achieve accuracy students have to be trained to extract the meaning from foreign texts by translation into the L1. A brief explanation of the meaning of words and phrases which might be time consuming can be done in the L1. Rivers (ibid) states that there is occasional translation of words and phrases as a check on comprehension of precise details in reading can be done through the L1. It offers clarification to some problems encountered by students and teachers such as losing the valuable time of the class in explaining the meaning of abstract words.

Humanistic approaches to language teaching regard L1 use as a supporting factor. They suppose that the L1 is a stage to give instructions when necessary. Larsen-Freeman (2011) states that the students' native language is used to make meaning clear. Students feel more secure when they understand everything. In addition, Gairns and Redman (2002) point out that translation can be a very effective way of conveying meaning especially when dealing with vocabulary items which have no equivalent in L1. Moreover, Little and Perclova (2001) point out that when working with beginners of any age, it is better to discuss learning goals, for example, in the L1 than not at all. Thus when teachers use the L1 to discuss learning goals with beginners, they should also summarize those goals in the target language (TL) and display the summary on a poster for future reference. When learners become more proficient, teachers should ensure that their reflection is conducted increasingly in the TL.

https://misuratau.edu.ly/journal/arts 
On the other hand, there is a belief that the use of L1 in any circumstances reduces opportunities for the use of the TL. Since teacher talk can be considered as an authentic input for communication, the focus should be on the use of TL. When teachers use simple and repeated expressions, later these expressions help students to understand new words and their functions. Gairns and Redman (2002) advise teachers not to overuse the L1 because it does not give students the essential spirit of the FL they actually need. It is worth noting that by using the TL a lot in the classroom, the students are encouraged to use it. This supports the achievement of successful communication which is the basic objective of teaching the FL. Moreover, Stern (2010) thinks that heavy reliance on translation may prevent the students from understanding and using the TL without much reference to the $\mathrm{L} 1$. This process hinders comprehension of the texts and makes the students depend on their L1 in recreation. According to Littlewood (2005), using the L1 in teaching means sacrificing valuable opportunities for well-motivated FL use. In addition, it tends to devalue the FL as a vehicle for communication. It is believed that in communicative language teaching (CLT) students should be exposed as much as possible to the TL to enable them to carry out routine classroom work. Students have to use the TL as a medium to organize any learning activities.

In relation to the English curricula of Libyan schools, it is clear that the CLT approach is adopted and there is no indication to the use of L1. The aim behind the compulsory use of the TL is to force both teachers and students to use it for the achievement of communicative competence. The only exception is when clarifying the instructions of the activities. In this case teachers may translate the instructions of how can the student do the activity, not doing the activity itself, especially at beginner levels.

Some aspects of the classroom behaviour of teachers who teach English language might be traditional and not in conformity with the principles and objectives of the communicative approach. According 
to Little (2010), the communicative approaches to language teaching recognize that 'naturalistic' language acquisition takes place as a result of communication, so they emphasize the role of communication not only as the goal but also as the channel of learning. However, some teachers still impose strict control on classroom practice and employ only teacher-fronted activities. Some teachers ignore the classroom affective factors that deal with students' emotions and desires; they do not consider students' ideas and contributions. Teachers use old teaching methods where they occupy the centre of the classroom and spend most of the class time talking, much more than students, using L1 extensively and little English during the lesson and students are drilled on grammar and sentence structure. Many teachers translate the difficult vocabulary items and expressions and sometimes use L1 in explaining the grammatical structures or the phonetic explanation of English. Edge (2005) advises teachers to run their classes in the TL to offer chances of more language exposure. The students know that the TL can be used for achieving communication. Consequently, they can acquire the language. He adds that using the TL introduces forms and uses of the language which the syllabus will not cover.

Teachers are asked to use the TL in the classroom, but they should recognise how to do that. Accordingly, Nunan (2015) states that teacher talk is important because the medium is the message. The modification which teachers make to their language, the questions they ask, the feedback they provide and the types of instructions and explanations they provide can all have an important bearing on the TL acquisition by learners. He adds that teacher talk is probably the major source of comprehensible TL input the learner is likely to receive. In addition, teachers' questions are very important to stimulate extended student responses. Students will improve more quickly if they are actively engaged in interaction than if they are passive. Good and Brophy (2007) argue that in teacher-fronted interactions, for instance, by distributing response opportunities widely, all learners are kept 
alert and given a chance to respond. Some students might appear to be passive in that they are not responding overtly, but they are mentally engaged in their lessons.

Another important issue is teacher feedback. Nunan (ibid) confirms that feedback can be classified as positive and negative. Behaviourist-inspired research has found that positive feedback is more effective than negative feedback. Positive feedback has two principal functions: to let students know that they have performed correctly, and to increase motivation through praise. Positive feedback may consist of short interjections of 'good', 'okay' and 'all right'. On the other hand, negative feedback may consist of the teacher's repeating the student's response with a rising intonation. Then, all students can recognize from this that an incorrect response has been given. In this regard, Willing (1988) confirms that learners expect feedback. In a major investigation of the learning preferences of adult ESL learners, error correction by the teacher was one of the most highly valued and desired classroom activities.

\subsection{Roles of teacher}

One central role of the teacher is to create and develop communicative activities. Ellis (2003) argues that language teaching materials are not in themselves communicative. They become communicative as a result of the way the materials are exploited by the teacher and student in the classroom. According to Ellis (ibid), it is the roles that student and teacher adopt that control the nature of the linguistic environment in the classroom. If the teacher adopts the traditional role of 'knower' and assigns the student role of 'information seeker', it is doubtful whether the resulting discourse will afford opportunities for using the primary processes. There are two other roles open to the teacher: those of 'onlooker' and 'partner'. In the role of onlooker, the teacher withdraws from the scene in favour of student-student activity. Student-student interaction is likely to be characterized by quantity of intake, a felt need to communicate, student control over the propositional content, adherence to the 'here- 
and-now' principle, the performance of a range of speech acts. In this way the opportunity for negotiation is secured as students are able to determine the relevance of their own utterances to the interaction. Informal activity such as symbol drawing and reconstruction of story sequences can be most effectively implemented in student-student interaction. Krashen (1981) argues that the language that learners address to each other may come quite close to meeting inputrequirements because it is more natural and more usually understood. The partner role involves the teacher providing only samples of L2 and guidance without rules. The teacher allows students to take the lead and then adjusts his own discourse contributions to provide an appropriate level of input. Partnership will work best in teacherstudent and teacher-group rather than teacher-class interaction. Allwright (2008) indicates that acting as 'partner' rather than 'knower' is not an abdication of responsibility. It is an acceptance of the necessity of sharing management activities in the classroom.

However, Ellis (2003) suggests some guidelines for determining suitable materials for fluency work. Firstly, there must be communicative purpose and not merely a pedagogic one. The test of whether there is or is not a communicative purpose is how successful completion of a task is judged; if the task is evaluated in terms of the behaviour outcome rather than its manner of performance, it is communicative. Secondly, the focus must be on message rather than on the channel; i.e. the participants must be concerned with what they have to say rather than how they are going to say it. Thirdly, there must be an information-gap i.e. one speaker must not know what the other speaker is going to say. Fourthly, the communication stimulated by the task must be negotiated rather than predetermined the task must not control the language to be used but must allow the speakers to make adaptations in content and expression in the light of the feedback they receive. Finally, the speakers must be allowed to use whatever resources - verbal and non-verbal - they posses, irrespective of whether these conform to normal native speaker behaviour or not. 


\subsection{Teachers scaffolding their students}

Ehrman (2007) mentions that some works on learning strategies describe external structures such as mechanical drilling and close guidance by the teacher that are used while a student is building skills as "scaffolding". Richards and Schmidt (2002) define scaffolding as the support provided to learners to enable them to perform tasks which are beyond their capacity. It is one way in which learners acquire new linguistic structures. The teacher and learners engage in a collaborative problem-solving activity with the teacher providing support, guidance and input and gradually withdrawing these as the learner becomes increasingly independent.

According to Ehrman (2007), the issue of appropriate support carries over from the beginning of the learning process, at which time more scaffolding is probably needed, to the advanced stages, in which less is likely to be needed because more skills have become automatic. The process of giving the right amount of external support is thus recursive - it comes up over and over again and at different levels of learning, from the smallest to the largest units. Some learners show great need for such scaffolding, whereas others need a lot as they begin each new learning task. For most students some amount of external structure is helpful or even necessary. Ehrman (ibid) confirms that appropriate support is giving the student what he needs now, not what was needed at the beginning of the course. Most students want and appreciate a lot of direct teacher support when they are beginning something new, e.g. a subject, a lesson, or a verb form.

\subsection{Teacher training}

Teacher training is very crucial (pre-service and in-service); if it is aimed to improve the way teachers behave in classrooms, there should be programmes of teacher education that develop their abilities and show them how to teach the language communicatively. Wallace (2001) indicates that when designing FL teacher education courses, it is worthwhile taking into consideration the following aims. First, 
trainees should understand the principles of language teaching based on current theories concerning language acquisition, linguistics, pedagogy, and the sociology and psychology of learning. Second, they must be shown how to apply these principles to their role of teaching of English. Third, trainees should be afforded opportunities to practice the teaching of English in a controlled way so that they will emerge as confident and competent classroom teachers. Also, trainees' competence and fluency in English should be developed so that they can communicate effectively as teachers and become good models of communication in the TL. Finally, the trainees' self-evaluation abilities should be developed and linked with an orientation towards autonomous learning which will enable them to improve their abilities as teachers once their initial training is over. Consequently, these trained teachers will be expected to demonstrate a grasp of the theory of language teaching methodology so that they will not only understand what methods are appropriate in a given situation but also why they are appropriate. Then, they will reveal an ability to modify their teaching strategies in the light of self-evaluation.

As basic principles relating to the overall design of a training course, Wallace (2001) argues that it should be educative to a high level, in terms of the trainees' personal and intellectual development. Simultaneously, the course should be fully professional and prepare the trainees for a practical profession such that its graduates are fully competent to assume their responsibilities in their career. Furthermore, the course must look beyond its own timespan to the continuing development of its graduates as autonomous professionals and reflective practitioners, and it should also lead trainees to greater autonomy by allowing them increasing independence of action as the course progresses. Wallace (ibid) clarifies that the methodology of teacher education should have a dual function: one function is to inform and teach the trainee both in terms of received knowledge and experiential knowledge. Another function is to provide exemplification of good teaching practice. This might mean that a 
variety of teaching modes should be used and the range of teaching methods may include: lectures, tutorials, seminars, workshops, practical work, microteaching and field work.

\section{Methodology}

\subsection{Participants}

The methodological approach underlies this study is a quantitative approach. The research study took place in four grade nine at fundamental stage schools in Misurata city. Three related but different questionnaires were submitted to three groups: 10 teachers, 40 students, and 8 inspectors of English. The questions in the three questionnaires were not identical, so each group was asked different questions to collect as much useful data as possible. The average age of the students was 15 years, ranging from $12-15$. They have studied English for nearly 6 years. They all spoke Arabic as their $1^{\text {st }}$ language. The participant teachers have variable years in their experience and qualification. The inspectors of English who supervise the teaching process in schools have participated in the study as well.

\subsection{Instrument and data collection}

In relation to the first group, 10 teachers, questionnaire consisted of multiple-choice questions and open questions. Regarding the students' questionnaire, it was conducted within three preparatory schools: two female schools and one male school. The received number of copies was 40. The students' questionnaire consisted of multiple-choice, yes-no questions and open-ended questions. The number of copies to English language inspectors was 8. The inspectors' questionnaire consisted of multiple-choice, yes-no questions and open-ended questions. After reminding the participants of the importance of giving honest answers, they were assured of the confidentiality of the data. The participants filled in the questionnaires, anonymously, and returned them back to the researcher. 


\subsection{Data analysis}

The survey was designed to provide essential background information and a general profile of beliefs about English language learning practices and ELT from three groups: teachers, students, and inspectors. Each group is an important part of the total picture. The questionnaire focused on the learner's needs, the role of the teacher and the textbook, and the difficulties in learning English such as the use of tenses, possessive articles, prepositions, verb "to have", and recognizing and producing the differences between some English sounds. It also sought to clarify the problems that are encountered during the process of ELT such as the use of L1 in English classrooms, students' interaction in the TL, length of class, time of class that students prefer, the techniques and teaching aids that are used in class, and the high number of students in classrooms.

\section{Findings and Results}

The survey findings are presented under four headings. (1) description of teachers' data; (2) description of students' data; (3) description of inspectors' data and (4) common issues among the three samples.

\subsection{Description of teachers' data}

Regarding teaching experience, $40 \%$ of the respondents had been teaching English for more than 6 years, 20\% for 5-6 years, 20\% for $3-4$ years, and $20 \%$ for $1-2$ years. On the other hand, $80 \%$ of the teachers were qualified with a Bachelor in English language whereas $20 \%$ had an intermediate diploma in English. Referring to the question of whether teaching English was interesting or boring, the results showed that $45 \%$ of the teachers rated it as very interesting, 55\% found it interesting and none of the respondents found it boring. In exploring what method teachers followed in teaching English, it was found that 55\% followed the Direct Method (DM), 40\% followed the audio-lingual method, and only $5 \%$ followed the communicative approach.

https://misuratau.edu.ly/journal/arts 
When teachers were asked whether they knew their students' names, 35\% answered that they knew all of them, $45 \%$ knew most of them, and $20 \%$ knew some of them. The length of lessons in schools is 40 minutes. It was found that $75 \%$ of the teachers thought this time was not sufficient to explain the main points of the lesson and give exercises, whereas $25 \%$ thought this time allowed them to do so. In addition, $30 \%$ of the teachers said they sometimes had enough time to practice the spoken language in class with their students, whereas 55\% said they rarely had time to practice, and $15 \%$ said they never had enough time to practice it. According to the survey results, $40 \%$ of the respondents replied that they always used English in teaching the lesson, but $60 \%$ said they sometimes did so.

As regards the appropriateness of the lessons' subjects to the students' age, $20 \%$ of the teachers said they were always appropriate and $80 \%$ said that lessons were sometimes appropriate. Asking about the type of homework that teachers give, it was found that memorizing vocabulary was given by $85 \%$, whereas grammar exercises were given by $80 \%$. Answering comprehension questions was given by $60 \%$, while reading texts was given by $40 \%$, and rewriting paragraphs was given by $20 \%$.

One of the questions to the teachers was about their responses when a student asks a question during their explanation of the lesson. It was found that $50 \%$ claimed that they listened to the question and gave an immediate answer, $45 \%$ said that they insisted on finishing what they were saying then answered the question, and 5\% replied that they ignored the question and went on with the lesson. Alternatively, it was found that $60 \%$ of the teachers judged that the behaviour of the student who interrupted them by asking questions or debating during the lesson was rude, while $40 \%$ judged this behaviour was good.

Interaction in the TL is very important for learners of L2. Nevertheless, it was found that $10 \%$ of the respondents said their 
students always engaged positively in interactions in class, whereas $65 \%$ said their students sometimes did, and 25\% said their students rarely interacted positively in class. The teachers' evaluation of their students' response in class varied; 5\% found their students' response was very good, $75 \%$ found it good, $15 \%$ found it weak, and $5 \%$ found it very weak. As regards using questions to motivate students' responses in class, it was found that $50 \%$ of the teachers said they always used questions in this way and $50 \%$ said they sometimes did so.

In terms of the activity type used in class, $60 \%$ of the respondents said they used both visual and audio activities in their classrooms, whereas $15 \%$ used audio only, and 5\% used visual only, and $20 \%$ used neither. This leads us to ask about the classroom techniques and teaching aids that they used in classroom activities. The answers to this question showed that $90 \%$ of the teachers used whiteboards, 55\% used pair-work, $15 \%$ used feedback, 35\% used roleplay, 10\% used story-telling, 20\% used correction, 30\% used groupwork, and $80 \%$ used questions and answers.

The teachers' response to whether their students preferred speaking lessons or grammar lessons varied: $10 \%$ said their students preferred speaking lessons, $45 \%$ said their students preferred grammar lessons, and $45 \%$ said they preferred both of them. Clarifying any specific difficulties students may encounter in learning English, teachers responded that $80 \%$ of students found it difficult to differentiate between the use of past simple tense and present perfect tense, whereas $20 \%$ said their students found it easy to recognize that. Also, $15 \%$ of teachers mentioned their students found the use of progressive tenses very difficult, $30 \%$ mentioned their students found them difficult, $45 \%$ mentioned their students found them easy, and only $10 \%$ mentioned their students found them very easy.

In Arabic language, nouns come before adjectives in a grammatically correct sentence. This is contrary to the English 
language, which may cause some difficulties to Libyan students. However, $50 \%$ of the teachers said their students found it difficult to use adjectives before nouns and 50\% said their students found it easy. Comparing the English language with the Arabic language, there are no possessive markers in Arabic, thus, $10 \%$ of the teachers said their students found the use of possessive markers such as 'of' and ' $s$ ' very difficult, whereas $50 \%$ said their students found it difficult, while $35 \%$ said their students found it easy and only 5\% said their students found it very easy. On the other hand, $10 \%$ of the teachers said their students found the use of prepositions in English very difficult and 75\% said their students found it difficult, whereas only $15 \%$ said their students found it easy. As to the use of the verb 'to have' as a main verb and as an auxiliary, $5 \%$ of the teachers said their students found it very difficult to differentiate between their uses, whereas $65 \%$ said their students found it difficult, while $25 \%$ said their students found it easy, and just 5\% said their students found it very easy.

Libyan students face some difficulties in pronouncing some English sounds. Asking the teachers how their students recognize and produce the difference between $|f|$ in feel and $/ v /$ in veal, it was found that $40 \%$ said their students found it difficult and 55\% said their students found it easy while only 5\% said their students found it very easy. The same question was asked about $/ p /$ in pack and $/ b /$ in back. It was found that $15 \%$ of teachers said their students found it very difficult to recognize and produce the difference between these two sounds, whereas $70 \%$ said their students found it difficult, while $10 \%$ said their students found it easy, and only 5\% said their students found it very easy. With respect to the difference in pronunciation between $/ \partial /$ in this and $/ \theta /$ in think, $15 \%$ of the teachers said their students found it very difficult to recognize and produce the difference, whereas $60 \%$ said their students found it difficult, while $20 \%$ said their students found it easy, and only 5\% said their students found it very easy. Given that the writing system in Arabic goes from right to left while English writing system goes from left to right, 5\% of 
teachers said their students found it difficult to learn the English writing system whereas $75 \%$ said their students found it easy and $20 \%$ said their students found it very easy to learn it. In addition $40 \%$ of the teachers said their students found it difficult to learn the use of punctuation, whereas $45 \%$ said their students found it easy, while $15 \%$ said their students found it very easy.

\subsection{Description of students' data}

When students were asked whether they liked learning English, 99\% answered Yes and only 1\% No. In addition, 97\% thought it is important to learn English whereas only 3\% thought it is not. To clarify the purpose of studying English, $60 \%$ of students answered that their aim in studying English in school was both to pass the exam and to learn the language itself, whereas $28 \%$ described their aim as solely to learn English and $12 \%$ merely aimed to pass the exam. Furthermore, $33 \%$ of these students found their English class very interesting, whereas $61 \%$ found it interesting while only $6 \%$ found it boring. To improve the learner's listening ability, they may listen to English music or watch English-speaking movies in their free time. However, only $32 \%$ of the students said they always did this, $48 \%$ said they sometimes did, while $12 \%$ said they rarely did and $8 \%$ said they never listened to any English music or watched any Englishspeaking movies.

Some students may look for private English courses in the evenings or during the summer holiday to improve their language. It was found that just $35 \%$ of the students took English courses while the majority, $65 \%$, did not. Though $31 \%$ of those who took these courses thought that the private courses were more useful for learning English, only 4\% thought the public school courses were. Questioning why students did not take extra courses to meet their needs for language skills, 31\% said they did not do so because of financial reasons, and just $4 \%$ said they had no desire to join these courses.

https://misuratau.edu.ly/journal/arts 
According to the survey results, $86 \%$ of the students said that the nationality of their English language teacher was Libyan, 14\% said their teacher was either Egyptian or Palestinian. In terms of understanding the teacher's pronunciation easily, $12 \%$ of the students said they always did, $68 \%$ said they sometimes did, whilst $20 \%$ said they rarely did. Most students preferred that their teacher explained the lesson in English, with 63\% agreed with this, whereas 37\% preferred that their teacher used Arabic in explaining the lesson. It was found that $8 \%$ of the students believed their teacher gave a lot of homework, whereas $61 \%$ said their teacher gave a reasonable amount, and $31 \%$ said their teacher did not give much homework.

In relation to the educational aids which students found most helpful, $50 \%$ of the students found the textbook most helpful, $40 \%$ found the white board most helpful, 39\% found video tapes most helpful, 38\% found CDs most helpful, 26\% found pictures most helpful, and $16 \%$ found real objects most helpful. Asking the students about the most difficult skill for them in learning English, 49\% said speaking, 22\% said writing, 15\% said listening, and 14\% said reading.

\subsection{Description of inspectors' data}

The inspectors of English are people who supervise the process of teaching the language in schools. First, all the inspectors agreed that there was a lack of qualified English teachers who can teach the syllabus appropriately in schools. Questioning whether teacher's use of Arabic in class would impede the students' language learning, 70\% felt that it would, while $30 \%$ did not think so. Considering the numbers of classes that students should have per week, $50 \%$ of the inspectors thought that they should have eight classes, 30\% thought they should have six classes and $20 \%$ thought they should have more than eight classes.

Enquiring about the proficiency of English teachers in explaining the lesson, $70 \%$ rated them as average whereas $30 \%$ rated them as weak. Furthermore, $60 \%$ of the inspectors gave a good mark 
to the teacher's preparation of the lesson and his organisation in class, whereas $30 \%$ gave a fair mark, while $10 \%$ gave a weak mark. Regarding the clarity of the lesson's aims, $10 \%$ of the inspectors said it was excellent, whereas $20 \%$ said it was good, while $60 \%$ said it was fair and $10 \%$ said it was weak. Regarding the presentation of the lesson, $50 \%$ of the inspectors said it was good and at a level that students can understand, 30\% said it was fair, and 20\% considered it weak. As for the variety of classroom activities, 30\% thought it was good, whereas $10 \%$ thought it was fair and $60 \%$ thought it was weak.

Considering the teachers' behaviour in class, $20 \%$ of the inspectors rated the teachers' initiative, resourcefulness and creativity as good, and $40 \%$ rated them as fair while $40 \%$ rated them as weak. Furthermore, $40 \%$ of the inspectors indicated that the teacher's ability to manage the classroom and direct the students was good, while $60 \%$ indicated them as only fair. On the other hand, $10 \%$ of the respondents said that the teacher's encouragement of the students and his emphasis on their sharing were excellent and $40 \%$ said they were good, $40 \%$ said they were fair and $10 \%$ said they were weak. However, $10 \%$ of the inspectors said that the teacher's recognition of the special needs of individuals and the general needs of the group was good, while $80 \%$ said it was fair, and $10 \%$ said it was weak.

\subsection{Common issues among all samples}

Concerning the time of holding English classes, it was found that $55 \%$ of teachers had both morning classes and afternoon classes while $45 \%$ had only morning classes. Comparing this with the students' preferences, $87 \%$ of the students preferred to have English classes in the morning session while $13 \%$ preferred to have them in the afternoon session.

Regarding the instructional aids and resources used in class, $30 \%$ of teachers said they used additional reference books, $35 \%$ used CDs, $10 \%$ used objects to handle, $90 \%$ used the text book, $5 \%$ used visual aids, 95\% used the white board, and $45 \%$ used pictures. 
Inspectors were asked to rate the level of teachers' use of instructional aids and resources; $70 \%$ considered it weak and 30\% considered it fair.

The high number of students in class is considered a big problem in Libyan schools; in relation to this, $10 \%$ of the teachers had a range of 21 to 25 students in their classes, $50 \%$ had classes of 26 to 30 students, while $40 \%$ had classes of more than 30 students. One of the recommended solutions for the high number of students in class is to divide them into smaller groups. It was found that $5 \%$ of teachers always divided their classes, whereas $25 \%$ sometimes did, while $25 \%$ rarely did, and $45 \%$ never did. Comparing to the students answer, it $5 \%$ of the respondents said their teacher rarely divided them into smaller groups while $95 \%$ said their teacher never did.

As for teaching vocabulary, the results of the teachers' data showed that $50 \%$ of them always translated the meanings of new words into Arabic, whereas 40\% sometimes did, while 5\% rarely did, and 5\% never translated the meanings. When students were asked what language their teacher used in class, they all answered both Arabic and English. The same question was asked to the inspectors of English. Their response was that $70 \%$ of teachers spent most of class time speaking in Arabic, where 30\% said teachers spent most of class time speaking in English.

Regarding teachers' opinion of students' feelings when they were asked to speak in English, 5\% replied that their students were confident and happy to speak another language, 70\% replied that their students felt shy and embarrassed about making mistakes, $15 \%$ replied that they felt other students will laugh at them, and only $20 \%$ replied that there was no particular feeling. Asking the students the same question, $26 \%$ answered that they felt happy to speak another language, 50\% were shy and embarrassed about making mistakes, 3\% felt that other students will laugh at them, and $21 \%$ had no particular feeling. Regarding whether teachers gave students thinking time to 
prepare their ideas and plan what to say in answering questions in class, $40 \%$ of the teachers said they always did this, whereas $50 \%$ replied that they sometimes did, and 10\% said they rarely did.

Regarding interaction in the TL away from school curriculum, $65 \%$ of teachers said students sometimes interacted with them and with each other co-operatively in English, whereas 35\% said it was rare for students to interact in English. According to the students' survey, $4 \%$ of the respondents said they always spoke English with friends outside the classroom, whereas $43 \%$ said they sometimes did, while 39\% rarely did, and 14\% never spoke English with friends outside the classroom.

As for doing homework, $30 \%$ of teachers said that their students always did their homework and 70\% said their students sometimes did. Comparing this with the students' response to the survey, $65 \%$ said they always completed their homework, while $30 \%$ said they sometimes did, and only 5\% said they rarely did. On the other hand, according to the results of teachers' data analysis, $55 \%$ of the teachers always corrected homework and $45 \%$ sometimes did. The students' response to the survey showed that $42 \%$ said their teacher corrected their homework and told them the mistakes they had made, $39 \%$ said their teacher sometimes did, 11\% said their teacher rarely did, and only $8 \%$ said their teacher never corrected it. In addition, $45 \%$ of teachers said they always used constructive comments in their marking and 55\% said they sometimes did.

Asking the inspectors whether teachers followed the instructions available in the teacher's book; $50 \%$ replied that they sometimes did and 50\% replied that they rarely did. According to the responses to the teachers' survey, $25 \%$ of teachers always followed these instructions, whereas $65 \%$ did sometimes, while $10 \%$ rarely did.

Inspectors rated the level of the clarity of the teacher's accent and the loudness of his/her voice, $30 \%$ of inspectors said it was good, whereas $50 \%$ said it was fair, and $20 \%$ said it was weak. By 
comparison, $33 \%$ of students said that their teacher's accent was always clear, whereas $56 \%$ said it was sometimes clear, and $11 \%$ said it was rarely clear.

\section{Discussion}

The survey reported the following main problems: teachers' following of traditional methods and the absence of training, the focus on teaching grammar rather than communicative activities, the use of Arabic in the classroom, the high number of students in class.

\subsection{General problems}

There are some common problems shared by all students and teachers. Some problems are presented through the interference of the L1 on the TL. For instance, the use of stress and intonation incorrectly, and the application of L1 grammatical rules in the TL as embodied in the use of adjectives, adverbs, or the verb to be. Some students attend English classes just to achieve a pass mark and not to learn the language itself; they consider it as any other class such as Maths or Geography. Besides lots of teachers consider teaching English in public schools as their merely job and do not care whether students learn how to use the language. On the other hand, other teachers complain that there is not sufficient time to give every participating student a chance to engage in the activities, especially if taking into consideration the high number of students, the number of class periods, and length of periods in a week.

Most of the modern methods of FL teaching focus on the importance of the speaking skill (interaction and production),but in this situation, after completing the fundamental stage students find themselves unable to sustain a discussion or a conversation. The weakness in the spoken method of learning English leads to other negative effects on their language learning. Their weakness becomes obvious when they begin to have conversations with their teachers and colleagues. 
In Libyan schools, more stress is laid on the student's eye and hand than on his/her ear or mouth. The four skills speaking, listening, reading and writing usually need equal attention. If more care is given to the reading and writing skills, this should not be a reason for neglecting the speaking and listening which are clearly not given the right amount of attention. The classroom situation, in this study, does not lead to a balance proficiency in all skills, because more stress is put on the written exam. Therefore, there are an increased number of passive students, who merely use their eyes in reading and their hands in writing and that is mainly to answer questions or do linguistic exercises. Students neglect anything that they expect not to come up in the final exam as the exam papers usually concentrate on reading and writing. It is common that a student can answer a written test in a satisfactory way, but cannot give a correct answer to a spoken question in English.

It is important to review the pronunciation problems encountered by students. If learners do not acquire an intelligible pronunciation in English, they may not be able to communicate with other people appropriately. Because students do not have exposure to authentic English, they will depend on their teacher to acquire the pronunciation. If their English teacher is not well qualified in teaching pronunciation, learners will face big difficulties in acquiring the language system. Therefore, teachers whose pronunciation is weak may cause pronunciation problems for their students.

\subsection{Teacher qualification and training difficulties}

An important problem is that some English teachers are not adequately prepared to teach English language proficiently as they are not trained enough to become teachers. Some of them are incompetent with teaching methodology and testing design and other programmes related to teaching. Many are unaware that communicative language teaching is the recommended approach to be followed in teaching the current syllabus. The low-level of English proficiency makes many

https://misuratau.edu.ly/journal/arts 
teachers resort to their $\mathrm{L} 1$ as a technique to cover the materials. This leads to a reduction in the amount of exposure to English in class. Most of teachers of English have never been trained by native speakers or exposed to authentic language interactions in native English-speaking countries.

Although the syllabus has been based on the Communicative Approach which calls for "student-centeredness", many classroom learning activities and the subjects' strategies are clearly still teacherdominated and not completely communicatively-based. Besides, teachers do not use the teachers' guidebook properly and some of them do not even have one. In fact, most of the teachers got used to applying the traditional views and objectives of teaching English language.

\section{Conclusion}

To conclude, there are many issues and difficulties which face teachers and students in learning and teaching English language in fundamental schools in Misurata city. As it is shown in the results of the study and the discussion, teachers should follow the modern methods and approaches of language teaching such as communicative language teaching. Teachers need to receive intensive training programs in teaching methodology to overcome the obstacles they encounter in their teaching. Furthermore, students have to familiarize themselves with communicative situations inside and outside classrooms to improve their language skills. Decreasing the use of the L1 is necessary and increasing the use of TL in classrooms.

Learners' enjoyment of L2 learning should come from the learners' self-realization and their sense that authentic development is being made. It is very clear that traditional methods were not very successful in teaching the English syllabus in schools because it follows the communicative way of teaching. Learning a language successfully needs a situation where the target language should be used. The TL needs to be the medium of instruction. Also it is central 
that English language teachers should focus on teaching students how to communicate effectively in the TL, though the only opportunity students have to communicate in English is in classroom and there is a little reinforcement outside the school. The problems which are identified from the survey showed that the lack of interaction in the TL both inside and outside the classroom and the focus on teaching grammar in class are major characteristics of ELT in this study.

\subsection{Recommendations}

- Urgent in-service training courses are needed for English language teachers to familiarize them with the latest developments in teaching English as a foreign language.

- Teachers should not teach what they find safe for them (grammar rules, isolated words) but should move their focus to helping students understand and use the language.

- Teachers should use the teacher's guide book and follow the instructions and implement them in their classes.

- Decreasing the use of Arabic language in class and giving more chance for students to interact in English.

\section{References}

Allwright, R. (2008). Abdication and Responsibility in Language

Teaching. Studies in Second Language Acquisition, 2(1), 105

-121. doi: https://doi.org/10.1017/S027226310000098X

Edge, J. (2005). Essentials of English Language Teaching $\left(5^{\text {th }}\right.$ ed.). London: Longman.

Ehrman, M. E. (2007). Understanding L2 Learning Difficulties ( $4^{\text {th }}$ ed.). USA: Sage Publications, Ltd.

Ellis, R. (2003). Classroom L2 Development (3th ed.). UK. Pergamon Press Ltd.

Gairns, R. \& Redman, S., (2002). Working with Words (3th ed.). Cambridge: Cambridge University Press. 
Good, T. \& J. Brophy. (2007). Looking in Classrooms. New York: Harper and Row.

Krashen, S. (2002). L2 Acquisition and L2 Learning. Oxford:

Pergamon Press. Retrieved from:

www.sdkrashen.com/content/books/sl_acquisition_and_learning.pdf

Larsen-Freeman, D. (2011). Techniques and Principles in Language Teaching. Oxford: Oxford University Press.

Little, D., \& Perclova, R. (2001). The European Language Portfolio:

A guide for teachers and teacher trainers. Strasbourg: Council of Europe.

Little, D. (2010). Learner Autonomy 1: definitions, issues, problems. ( $6^{\text {th }}$ ed.). Dublin: Authentic.

Littlewood, W. (2005). Communicative Language Teaching.(3th ed.). Cambridge: Cambridge University Press.

Macfarlane, M., \& Farrell, M. (2004). English for Libya: preparatory ,teacher'sbook. ( $4^{\text {th }}$ ed.). UK. Garnet Publishing Ltd.

Nunan, D. (2015). Language Teaching Methodology: A Textbook for Teacher. NJ. Prentice Hall.

Phillips, T., Tankard, F., Phillips, A., Lucantoni, P., \& Tankard A. (2000). English for Libya:secondary 2 English language and communication,teacher's book. UK: Garnet Publishing Ltd.

Richards, J. C., \& Schmidt, R. (2002). Longman Dictionary of Language Teaching \& AppliedLinguistics. ( $3^{\text {rd }}$ ed.). London: Person Education Limited.

Rivers, W. A. (2015). Teaching Foreign Language Skills. Retrieved from: https://archive.org/details/teachingforeign10000rive

Stern, H. (2010). Issues and Options in Language Teaching. Oxford: Oxford University Press.

Wallace, M., J. (2001). Training Foreign Language Teachers. A reflective approach. Great Britain. Bell \& Bain Ltd.

Willing, K. (1988). Learning Strategies in Adult Migrant Education. Adelaide: NCRC. 